\title{
STUDY OF URINARY CONCENTRATIONS OF MANDELIC ACID IN EMPLOYEES EXPOSED TO STYRENE
}

\author{
Mária Poláková1, Zdenka Krajčovičová2, Vladimír Meluš², Mária Štefkovičová1, Margaréta Šulcová3 \\ ${ }^{1}$ Regional Authority of Public Health, Trenčín, Slovak Republic \\ ${ }^{2}$ Department of Laboratory Medicine, Faculty of Healthcare, Alexander Dubček University of Trenčín, Trenčín, Slovak Republic \\ ${ }^{3}$ Department of Occupational Health, Faculty of Public Health, Slovak Medical University, Bratislava, Slovak Republic
}

\section{SUMMARY}

Mandelic acid (MA) is an important metabolite of styrene. In humans, measurement of its concentration in urine provides an important assessment of the overall level of styrene exposure in workers of the reinforced plastic manufacturing industry. The aim of our study was to investigate in these workers the relationship between MA concentration and styrene exposure time and intensity as well as its dependence on work occupation.

The concentration of MA in the urine samples of 35 employees was analyzed with HPLC (High Performance Liquid Chromatography). Out of 35 workers, 11 performed laminating, 11 milling and finalizing, 6 laying-up and spraying-up, and 7 worked in background support. Urinal samples were obtained twice a day over the course of three weeks, at the beginning and the end of the work shift.

We found a significant increase in MA concentrations during a work shift in all tested days (Wilcoxon test $p<0.05$ ). Employees working in elevated atmospheric concentrations of styrene $\left(93.77-159.88 \mathrm{mg} / \mathrm{m}^{3}\right)$ had significantly higher MA concentrations in urine compared to other groups at both the beginning and the end of the shift (Kruskal Wallis test $p<0.001)(p<0.001)$. Only samples from laminating workers exceeded the biological limit of MA concentration $(640 \mathrm{mg} / \mathrm{L}$ ) at the end of the shift. Normalisation of MA concentration to body mass index (BMI, normal range: $21.7 \pm 3.2 \mathrm{~kg} / \mathrm{m}^{2}$ ) refined differences within groups (Kruskal-Wallis analysis $p<0.001$ ). The accumulation of MA at the end of the work shift for measured time period was not significant for the measured time period (Friedman analysis $p>0.11$ ).

Our results confirmed that MA is a sensitive metabolic marker of styrene exposure without cumulative effect. However, normalization of MA concentrations to BMI can improve the accuracy of styrene exposure estimates in certain groups of employees.

Key words: styrene, mandelic acid, exposure, BMI

Address for correspondence: Zdenka Krajčovičová, Department of Laboratory Medicine, Faculty of Healthcare, Alexander Dubček University of Trenčín, Študentská 2, 91101 Trenčín, Slovak Republic. E-mail: zdenka.krajcovicova@gmail.com

\section{INTRODUCTION}

Styrene (vinylbenzene, Fig. 1A) is a commercially important chemical widely used in manufacturing of synthetic rubber, resins, polyesters, and plastics. Styrene is also an environmental contaminant and is present in small quantities in food items, tobacco smoke and engine exhausts (1-4).

The highest level of human exposure to styrene occurs in occupational settings, especially during manufacturing of reinforced plastic products, which involve manual lay-up or spray-up operations. In these settings, absorption of styrene occurs mainly through inhalation and, to a minor extent, via skin contact. Once inside the body, styrene is widely distributed. The distribution and sequestration of styrene to fat tissue and its subsequent slow elimination indicate a potential for accumulation in cases of repeated daily exposure (5). Styrene exposure has been reported to cause an increase in DNA and haemoglobin adducts as well as in the frequency of chromosomal aberrations. There is also some evidence for an association between styrene exposure and the frequency of sister chromatid exchanges (4).
Styrene provides positive results in many toxicology assays (1). The acute neurotoxic effect of occupational exposure to high levels of styrene is characterized by prenarcotic depression of the central nervous system. Symptoms include drowsiness, lightheadedness, dizziness, headache, tiredness, and loss of balance. These effects have been reported in reinforced plastics workers exposed to airborne concentrations above $100 \mathrm{ppm}$. Toxicological studies have also identified other neurotoxic effects of styrene, including disruption of dopaminergic functions of the brain as well as changes in nerve conduction and neurobehavioural test performance (4).

Although strong evidence for the carcinogenicity of styrene in humans and animals is currently lacking, the IARC has classified styrene as a possible human carcinogen (group 2B) (4). The available epidemiological evidence does not support a causal relationship between styrene exposure and any type of human cancer. It has been found that there is no consistently increased risk of any type of cancer among workers exposed to styrene $(6,7)$. A study of reinforced plastics workers reported an association between average estimated styrene exposure and 
A

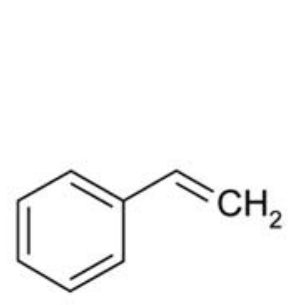

B

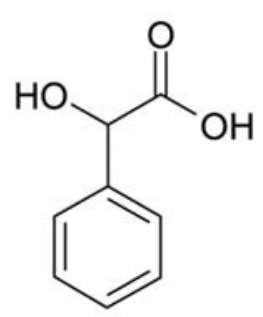

Fig. 1. Structures of (A) styrene and (B) mandelic acid.

non-Hodgkin lymphoma (NHL) (8). Other studies of styrene exposure and NHL have found no increased risk $(6,7)$. In two US studies of reinforced plastics workers, esophageal cancer mortality was increased, but these findings were generated on a background of multiple comparisons. Results for other cancers were unremarkable (6).

In humans, the metabolism of styrene is well characterized (4). The majority of the absorbed material (approx. 90\%) in humans is metabolized in the liver by oxidation of the vinyl side group to styrene oxide. A key step in the metabolism of styrene is its oxidation by cytochrome $\mathrm{P} 450$ enzymes which converts styrene to its reactive metabolite styrene-7, 8-oxide (SO) (9). It is a form of styrene that is considered responsible for its genotoxic effects, as it binds covalently with macromolecules. SO is mainly hydrolyzed to styrene glycol by the microsomal epoxide hydrolase, and is subsequently oxidized by alcohol and aldehyde dehydrogenases to form the main urinary metabolites, mandelic acid (2-hydroxy-2phenylacetic acid; MA; Fig. 1B) and phenylglyoxylic acid (PGA) (major pathway). Together, MA and PGA represent more than 95\% of the urinary of styrene metabolites. Further transformation of MA and PGA through transamination of $\alpha$-keto- and $\alpha$-hydroxy acids into the corresponding amino acids leads to the formation of phenylglycine (4).

The metabolites MA and/or PGA in end-shift urine have generally been the biomarkers of choice for evaluation of styrene exposure, although blood styrene in end-shift samples has also been recommended for this purpose. Other metabolites of styrene have recently been proposed as biomarkers of styrene exposure (10-16), including a mixture of diastereomeric mercapturic acids, [(R,R)- and (S,R)-N-acetyl-S-(1-phenyl-2hydroxyethyl)-l-cysteine and (R,R)- and (S,R)-N-acetyl-S-(2phenyl-2-hydroxyethyl)-1-cysteine], 4-vinylphenol, excreted as a glucuronide and sulfate conjugates, phenylglycine and urinary styrene.

The aim of our study was to uncover in workers of the reinforced plastic manufacturing industry the relationships between MA concentration and styrene exposure time and intensity, as well as its dependence on the kind of work occupation.

\section{MATERIALS AND METHODS}

\section{Chemicals}

Mandelic acid, anhydrous potassium dihydrogenphosphate and acetonitrile (LiChrosolv grade) were obtained from Merck, Darmstadt, Germany. Decasulfonate sodium was bought from
Fluka Chemie AG, Switzerland. Milli-Q (Millipore, Bedford, MA, USA) deionized water was used for all aqueous solutions.

\section{Urine Samples}

We examined 35 employees working in a single shift operation of a company specializing in fiberglass laminate production, utilizing styrene in production process. Out of 35, 11 workers, the laminators, were the most exposed to styrene, working chiefly in the styrene-saturated ambient air. Another 11 people were involved in milling and finalizing work. Six workers performed laying-up and spraying-up work and a further 7 people were involved in background support work (cleaners, administrators, director, and storeman).

Urine samples from these 35 workers were collected twice a day over the course of three weeks on Monday, Tuesday, Thursday and Friday, at the beginning and the end of the workshift. Samples were stored at $-20^{\circ} \mathrm{C}$ until analysis (less than 3 months). For HPLC analysis urine samples were diluted centrifuged at 3000 rpm for $10 \mathrm{~min}$ and an aliquot of $10 \mu \mathrm{l}$ was injected directly into the chromatographic system.

\section{Equipment and Chromatographic Conditions}

The HPLC system consisted of a Varian model 9012 and a UV-VIS detector Varian model 9050, all from Varian. Varian Star Workstation v4.5 software (Varian) was used for system and data management. The separation was performed at a 0.3 $\mathrm{ml} / \mathrm{min}$ flow-rate, from $10 \mathrm{~min} 0.4 \mathrm{ml} / \mathrm{min}$ flow-rate and $25^{\circ} \mathrm{C}$ on a Varian C18 Inertsil 5 ODS-2 cartridge column (250 x 3.0 $\mathrm{mm})$ with a Chromsep guard column $(10 \times 2 \mathrm{~mm})$ packed with Symmetry C18. The mobile phase was a mixture of phosphate buffer $\left(20 \mathrm{mM} \mathrm{KH}_{2} \mathrm{PO}_{4}\right.$ in deionized water, with $3 \mathrm{mmol} / 1$ decasulfonate sodium; $\mathrm{pH}=3.3$ ) and acetonitrile 85:15 (w/w) (17). The UV-VIS absorbance over the 195-400 nm range was recorded and the wavelength used for quantification was 225 $\mathrm{nm}$ for all compounds.

\section{Air Consumption}

The samples of air were taken from the respiratory zone of all 35 workers twice a day over the course of three weeks on Monday, Tuesday, Thursday and Friday, at the beginning and the end of the workshift. Samples were taken by means of personal assay pumps (SKC AirChek 52, 2000) with flow in the range from 0.20 to $0.30 \mathrm{l} / \mathrm{min}$. to sorbent tubes SKC filled with charcoal coconut. Afterwards, the samples have been eluated with carbon disulphide and analyzed by the GC/MS method.

\section{Statistical Analysis}

For description of individual groups the arithmetic mean (M) and standard deviation (SD) were used. As the data was found to be non-normal, medians, minimum and maximum values are also given. The non-parametric Wilcoxon matched-pairs test was applied to evaluate the statistical significance of the difference between two related groups. Comparison of more than 3 dependent variables was performed with the non-parametric Friedman test. Differences amongst independent variables were analyzed with the non-parametric Kruskal-Wallis test followed by the Dunn's post test, or in the case of compared categories pairs, the non-parametric Mann-Whitney U-test. Test results were considered to be statistically significant at $p<0.05$. 


\section{RESULTS AND DISCUSSION}

In the plastics manufacturing process, styrene serves as a solvent and as a reactant for the unsaturated polyester resin, in which it constitutes approx. $40 \%$ by weight. During the process of lamination and curing, about $10 \%$ of styrene may evaporate into the workplace air (18). In our investigation, the mean concentrations of styrene were found to be within the range $93.77-159.88 \mathrm{mg} /$ $\mathrm{m}^{3}$ (21.7-37 ppm). According to the current legislative in force, the highest permissible exposure limit (HPEL) for styrene is 86 $\mathrm{mg} / \mathrm{m}^{3}$ (20 ppm) (19). Therefore, we can conclude that laminators and workers performed laying-up and spraying-up operations are working in elevated atmospheric concentrations of styrene in comparison with HPEL of styrene in the Slovak Republic. Concentrations of styrene in the atmosphere of other employees involved in milling and finalizing work and in background support work were under the limit of quantification by GC/MS method.

We first tested the hypothesis that increased exposure to styrene leads to increased concentration of urinary MA (Tables 1 and 2). At the beginning of the work day, there are statistically significant differences in MA concentration between workers of different professions. The Kruskal-Wallis test showed $\mathrm{p}<0.001$ for all tested days (Table 1). While there was no significant difference in MA concentration between employees carrying out laminating work and those involved in laying and spraying up, MA concentrations in laminating workers were significantly higher than those of two other groups (milling and finalizing and background support). The same differences were observed at the end of the work shift, although at this stage all workers exhibited substantially elevated concentrations of MA. Kruskal-
Wallis analysis once again revealed $\mathrm{p}<0.001$ for all tested days (Table 2).

There are two possible explanations for this observation. Either the concentration of styrene at the workplace of laminating workers is high to enable it to rapidly enter into human metabolism prior to the collection of the first urine sample, or it is the retention of accumulated styrene metabolites observed by laminators. Respirators and appropriate protective clothing prevent the direct contact of the external styrene-saturated atmosphere with the body. Usage of such a protective measures by employees, who are directly involved in the fiberglass laminating process, can also substantially affect the MA concentrations.

A second interesting observation is that only in the most styreneexposed profession (laminators) did MA concentrations exceed the given biological exposure limit value of $640 \mathrm{mg} / \mathrm{L}$ at the end of working period. Another three professions had not such high values (Table 2). Our testing revealed significant differences of MA concentrations between the morning and postshift urine samples in all days for almost all tested categories $(\mathrm{p}<0.05$, Wilcoxon test, Table 3). The only exceptions were the data for Monday/laminating and Monday/laying-up and spraying-up, where employees had no detectable concentrations of MA (limit of detection $0.762 \mathrm{mg} / \mathrm{L}$ ).

We were aware of the diagnostic limits of results due to differences in the individual metabolism of each worker. Even normalization to 24-hour creatinine levels could be potentially misleading, as the personal anamneses of individual employees were unavailable. There are simply too many factors influencing creatinine excretion in individuals to make it a reliable read-out of individual metabolism. To address this issue, we took advantage of the body mass index measurements of the workers (BMI, units

Table 1. Concentrations of mandelic acid in $\mathrm{mg} / \mathrm{L}$ collected at the beginning of the work shift

\begin{tabular}{|c|c|c|c|c|c|c|c|c|c|c|c|c|}
\hline \multirow[t]{2}{*}{ Day } & \multirow[t]{2}{*}{ Profession } & \multicolumn{6}{|c|}{$\begin{array}{c}\text { Statistical analysis } \\
\text { Descriptive statistics }\end{array}$} & \multirow{2}{*}{$\begin{array}{c}\text { Kruskal- } \\
\text { Wallis } \\
\text { test }\end{array}$} & \multicolumn{4}{|c|}{ Dunn's multiple test } \\
\hline & & $\mathrm{n}$ & $M$ & SD & Med & Min & Max & & 1 & 2 & 3 & 4 \\
\hline \multirow{4}{*}{$\frac{\vec{\pi}}{\frac{\pi}{0}}$} & 1 & 11 & 253.10 & 166.41 & 180.40 & 82.60 & 591.60 & \multirow{4}{*}{ t++ } & - & +++ & ns & +++ \\
\hline & 2 & 11 & 0.76 & - & 0.76 & 0.76 & 0.76 & & +++ & - & ns & ns \\
\hline & 3 & 6 & 39.40 & 45.53 & 20.75 & 3.00 & 107.30 & & ns & ns & - & ns \\
\hline & 4 & 7 & 0.76 & - & 0.76 & 0.76 & 0.76 & & +++ & ns & ns & - \\
\hline \multirow{4}{*}{ 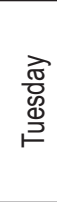 } & 1 & 11 & 296.28 & 110.46 & 277.00 & 140.20 & 484.30 & \multirow{4}{*}{+++} & - & +++ & ns & +++ \\
\hline & 2 & 11 & 38.75 & 47.5 & 0.76 & 0.76 & 131.30 & & +++ & - & ns & ns \\
\hline & 3 & 6 & 84.12 & 64.94 & 81.00 & 3.00 & 186.00 & & ns & ns & - & ns \\
\hline & 4 & 7 & 2.04 & 1.20 & 3.00 & 0.76 & 3.00 & & +++ & ns & ns & - \\
\hline \multirow{4}{*}{ 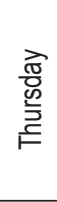 } & 1 & 11 & 271.10 & 129.88 & 288.10 & 89.60 & 565.50 & \multirow{4}{*}{+++} & - & ++ & ns & +++ \\
\hline & 2 & 11 & 56.17 & 65.90 & 35.80 & 0.76 & 168.10 & & ++ & - & ns & ns \\
\hline & 3 & 6 & 93.50 & 27.73 & 92.20 & 54.20 & 136.00 & & ns & ns & - & ns \\
\hline & 4 & 7 & 11.05 & 24.30 & 3.00 & 0.76 & 66.10 & & +++ & ns & ns & - \\
\hline \multirow{4}{*}{ 른 } & 1 & 11 & 262.28 & 89.71 & 279.30 & 41.60 & 390.90 & \multirow{4}{*}{+++} & - & ++ & ns & +++ \\
\hline & 2 & 11 & 62.38 & 56.38 & 51.20 & 0.76 & 187.50 & & ++ & - & ns & ns \\
\hline & 3 & 6 & 112.23 & 36.63 & 127.65 & 65.50 & 146.00 & & ns & ns & - & ns \\
\hline & 4 & 7 & 15.17 & 22.43 & 3.00 & 0.76 & 51.20 & & +++ & ns & ns & - \\
\hline
\end{tabular}

Concentrations of mandelic acid are expressed as the arithmetical mean of values collected over the course of three weeks. $\mathrm{N}-$ number of individuals, M - arithmetical mean, SD - standard deviation, Med - median, Min - minimum value, Max - maximum value. Significance of test results: $++p<0.01 ;+++p<0.001$; ns $p>0.05$. Profession: 1 - laminating, 2 - milling and finalizing, 3 - laying-up, spraying-up, $4-$ background support 
Table 2. Concentrations of mandelic acid in $\mathrm{mg} / \mathrm{L}$ collected at the end of the work shift

\begin{tabular}{|c|c|c|c|c|c|c|c|c|c|c|c|c|}
\hline \multirow[t]{2}{*}{ Day } & \multirow[t]{2}{*}{ Profession } & \multicolumn{6}{|c|}{$\begin{array}{l}\text { Statistical analysis } \\
\text { Descriptive statistics }\end{array}$} & \multirow{2}{*}{$\begin{array}{c}\text { Kruskal- } \\
\text { Wallis } \\
\text { test }\end{array}$} & \multicolumn{4}{|c|}{ Dunn's multiple test } \\
\hline & & $\mathrm{n}$ & M & SD & Med & Min & Max & & 1 & 2 & 3 & 4 \\
\hline \multirow{4}{*}{$\begin{array}{l}\text { ते } \\
\frac{0}{0} \\
\Sigma\end{array}$} & 1 & 11 & 824.00 & 547.09 & 763.90 & 201.20 & 2016.7 & \multirow{4}{*}{ +++ } & - & +++ & ns & +++ \\
\hline & 2 & 11 & 122.78 & 36.94 & 129.6 & 68.20 & 190.50 & & +++ & - & ns & ns \\
\hline & 3 & 6 & 188.95 & 82.83 & 161.55 & 114.80 & 310.10 & & ns & ns & - & ns \\
\hline & 4 & 7 & 104.84 & 48.45 & 90.10 & 57.30 & 188.10 & & +++ & ns & ns & - \\
\hline \multirow{4}{*}{ 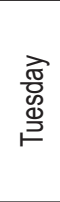 } & 1 & 11 & 786.53 & 400.33 & 804.70 & 220.60 & 1471.20 & \multirow{4}{*}{+++} & - & +++ & ns & t++ \\
\hline & 2 & 11 & 145.80 & 60.05 & 143.70 & 65.10 & 129.20 & & +++ & - & ns & ns \\
\hline & 3 & 6 & 288.87 & 82.29 & 305.40 & 137.40 & 376.50 & & ns & ns & - & ns \\
\hline & 4 & 7 & 111.87 & 42.20 & 119.30 & 31.00 & 165.60 & & +++ & $\mathrm{ns}$ & ns & - \\
\hline \multirow{4}{*}{$\begin{array}{l}\text { त्ञ } \\
\text { 总 } \\
\text { F }\end{array}$} & 1 & 11 & 761.28 & 208.96 & 711.10 & 529.50 & 1239.70 & \multirow{4}{*}{+++} & - & +++ & ns & +++ \\
\hline & 2 & 11 & 170.15 & 74.39 & 141.9 & 100.60 & 310.90 & & +++ & - & ns & ns \\
\hline & 3 & 6 & 249.69 & 97.21 & 232.85 & 145.80 & 422.40 & & ns & ns & - & ns \\
\hline & 4 & 7 & 127.59 & 71.46 & 115.70 & 37.90 & 246.90 & & +++ & ns & ns & - \\
\hline \multirow{4}{*}{$\begin{array}{l}\text { 흔 } \\
\text { 는 }\end{array}$} & 1 & 11 & 1011.75 & 617.70 & 865.90 & 321.30 & 2641.90 & \multirow{4}{*}{+++} & - & +++ & ns & +++ \\
\hline & 2 & 11 & 210.65 & 120.60 & 178.40 & 135.40 & 473.20 & & +++ & - & ns & ns \\
\hline & 3 & 6 & 278.97 & 79.62 & 280.70 & 189.00 & 408.60 & & ns & ns & - & ns \\
\hline & 4 & 7 & 109.70 & 63.95 & 76.10 & 60.40 & 220.10 & & +++ & $\mathrm{ns}$ & ns & - \\
\hline
\end{tabular}

Concentrations of mandelic acid are expressed as the arithmetical mean of values collected over the course of three weeks. $\mathrm{N}-$ number of individuals, $\mathrm{M}-$ arithmetical mean, SD - standard deviation, Med - median, Min - minimum value, Max - maximum value, Significance of test results: +++ $p<0.001$; ns $p>0.05$. Profession: 1 - laminating, 2 - milling and finalizing, 3 - laying-up, spraying-up, 4 - background support. Numerical values of means and medians above biological limit of mandelic acid (640 $\mathrm{mg} / \mathrm{L})$ are accentuated in bold.

Table 3. Increase of mandelic acid concentrations $(\mathrm{mg} / \mathrm{L})$ during the work shift

\begin{tabular}{|c|c|c|c|c|c|c|c|c|}
\hline \multirow{2}{*}{ Day } & \multirow{2}{*}{ Profession } & \multicolumn{3}{|c|}{ The beginning of the shift } & \multicolumn{3}{|c|}{ The end of the shift } & \multirow{2}{*}{$\mathrm{p}$} \\
\hline & & Med & Min & Max & Med & Min & Max & \\
\hline \multirow{4}{*}{$\begin{array}{l}\frac{\vec{d}}{0} \\
\frac{0}{2}\end{array}$} & 1 & 180.40 & 82.60 & 591.60 & 763.90 & 201.20 & 2016.7 & +++ \\
\hline & 2 & 0.76 & 0.76 & 0.76 & 129.6 & 68.20 & 190.50 & - \\
\hline & 3 & 20.75 & 3.00 & 107.30 & 161.55 & 114.80 & 310.10 & + \\
\hline & 4 & 0.76 & 0.76 & 0.76 & 90.10 & 57.30 & 188.10 & - \\
\hline \multirow{4}{*}{ 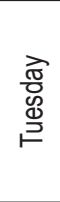 } & 1 & 277.00 & 140.20 & 484.30 & 804.70 & 220.60 & 1471.20 & +++ \\
\hline & 2 & 0.76 & 0.76 & 131.30 & 143.70 & 65.10 & 129.20 & +++ \\
\hline & 3 & 81.00 & 3.00 & 186.00 & 305.40 & 137.40 & 376.50 & + \\
\hline & 4 & 3.00 & 0.76 & 3.00 & 119.30 & 31.00 & 165.60 & + \\
\hline \multirow{4}{*}{ 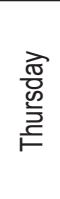 } & 1 & 288.10 & 89.60 & 565.50 & 711.10 & 529.50 & 1239.70 & +++ \\
\hline & 2 & 35.80 & 0.76 & 168.10 & 141.9 & 100.60 & 310.90 & +++ \\
\hline & 3 & 92.20 & 54.20 & 136.00 & 232.85 & 145.80 & 422.40 & + \\
\hline & 4 & 3.00 & 0.76 & 66.10 & 115.70 & 37.90 & 246.90 & + \\
\hline \multirow{4}{*}{ 离 } & 1 & 279.30 & 41.60 & 390.90 & 865.90 & 321.30 & 2641.90 & +++ \\
\hline & 2 & 51.20 & 0.76 & 187.50 & 178.40 & 135.40 & 473.20 & +++ \\
\hline & 3 & 127.65 & 65.50 & 146.00 & 280.70 & 189.00 & 408.60 & + \\
\hline & 4 & 3.00 & 0.76 & 51.20 & 76.10 & 60.40 & 220.10 & + \\
\hline
\end{tabular}

Concentrations of mandelic acid are expressed as the arithmetical mean of values collected over the course of three weeks. Med - median, Min - minimum value, Max maximum value, $p-$ significance level of Wilcoxon test results: $+p<0.05 ;+++p<0.001$. Profession: $1-$ laminating, $2-$ milling and finalizing, $3-$ laying-up, spraying-up,

4 - background support. Numerical values of means and medians above biological limit of mandelic acid (640 mg/L) are accentuated in bold.

$\left.\mathrm{kg} / \mathrm{m}^{2}\right)$. BMI values are given in Table 4 . From Table 4 is apparent that while the workers as a whole had normal BMI $(23.81 \pm 3.2$ $\mathrm{kg} / \mathrm{m}^{2}$ ), the BMI values of workers varied significantly between different occupations. Employees engaged in milling and finalizing as well as those performing laying and spraying-up operations tended to have higher than normal BMI values (Table 4). 
Table 4. Body mass index in professions

\begin{tabular}{|c|c|c|c|c|c|c|c|c|c|c|c|}
\hline \multirow{2}{*}{ Profession } & \multicolumn{6}{|c|}{ Statistical analysis } & \multirow{2}{*}{$\begin{array}{l}\text { Kruskal- } \\
\text { Wallis test }\end{array}$} & \multicolumn{4}{|c|}{ Dunn's post test } \\
\hline & $\mathrm{n}$ & M & SD & Med & Min & Max & & 1 & 2 & 3 & 4 \\
\hline 1 & 11 & 22.22 & 1.14 & 22.00 & 20.50 & 24.10 & \multirow{4}{*}{+} & - & ns & + & ns \\
\hline 2 & 11 & 24.17 & 3.08 & 25.90 & 17.60 & 27.80 & & ns & - & ns & ns \\
\hline 3 & 6 & 27.38 & 3.42 & 27.95 & 22.00 & 31.60 & & + & ns & - & + \\
\hline 4 & 7 & 22.70 & 3.43 & 21.50 & 20.20 & 30.20 & & ns & ns & + & - \\
\hline
\end{tabular}

$\mathrm{N}$ - number of individuals, $\mathrm{M}$ - arithmetical mean, SD - standard deviation, Med - median, Min - minimum value, Max - maximum value, Significance of Kruskal-Wallis test results: $+p<0.05 ; n s p>0.05$. Profession: 1 - laminating, 2 - milling and finalizing, 3 - laying-up and spraying-up, 4 - background support. Numerical values of means and medians above BMI limit $\left(24.9 \mathrm{~kg} / \mathrm{m}^{2}\right)$ are accentuated in bold.

Table 5. Differences in mandelic acid concentrations $(\mathrm{mg} / \mathrm{L})$ in professions collected after the shift and extrapolated to BMI

\begin{tabular}{|c|c|c|c|c|c|c|c|c|c|c|c|c|}
\hline \multirow[t]{2}{*}{ Day } & \multirow[t]{2}{*}{ Profession } & \multicolumn{6}{|c|}{$\begin{array}{l}\text { Statistical analysis } \\
\text { Descriptive statistics }\end{array}$} & \multirow{2}{*}{$\begin{array}{l}\text { Kruskal- } \\
\text { Wallis test }\end{array}$} & \multicolumn{4}{|c|}{ Dunn's multiple test } \\
\hline & & $\mathrm{n}$ & M & SD & Med & Min & $\operatorname{Max}$ & & 1 & 2 & 3 & 4 \\
\hline \multirow{4}{*}{$\begin{array}{l}\frac{\vec{\pi}}{0} \\
\frac{0}{2}\end{array}$} & 1 & 11 & 25.60 & 24.13 & 19.22 & 0.98 & 83.04 & \multirow{4}{*}{+} & - & ns & ns & + \\
\hline & 2 & 11 & 5.13 & 1.66 & 5.05 & 2.52 & 7.46 & & ns & - & ns & ns \\
\hline & 3 & 6 & 5.65 & 2.68 & 4.89 & 3.37 & 10.55 & & ns & ns & - & ns \\
\hline & 4 & 7 & 4.61 & 2.23 & 4.02 & 2.63 & 9.27 & & + & ns & ns & - \\
\hline \multirow{4}{*}{ 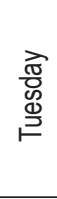 } & 1 & 11 & 22.13 & 17.15 & 19.07 & 2.95 & 58.77 & \multirow{4}{*}{++} & - & ++ & ns & + \\
\hline & 2 & 11 & 4.66 & 2.60 & 4.19 & 2.22 & 10.45 & & ++ & - & ns & ns \\
\hline & 3 & 6 & 7.68 & 2.29 & 8.01 & 4.53 & 10.06 & & ns & ns & - & ns \\
\hline & 4 & 7 & 4.91 & 2.04 & 5.20 & 1.41 & 8.05 & & + & $\mathrm{ns}$ & ns & - \\
\hline \multirow{4}{*}{ 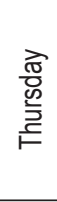 } & 1 & 11 & 22.13 & 7.77 & 20.88 & 11.18 & 36.17 & \multirow{4}{*}{+++} & - & +++ & ++ & ++ \\
\hline & 2 & 11 & 4.77 & 1.33 & 4.69 & 2.40 & 6.74 & & +++ & - & ns & ns \\
\hline & 3 & 6 & 5.88 & 3.70 & 4.88 & 1.99 & 12.50 & & ++ & ns & - & ns \\
\hline & 4 & 7 & 5.29 & 2.84 & 5.18 & 1.73 & 9.30 & & ++ & ns & ns & - \\
\hline \multirow{4}{*}{ 흔 } & 1 & 11 & 34.36 & 29.79 & 24.35 & 4.51 & 115.25 & \multirow{4}{*}{+++} & - & ++ & + & ++ \\
\hline & 2 & 11 & 6.13 & 2.80 & 6.30 & 2.64 & 10.96 & & ++ & - & ns & ns \\
\hline & 3 & 6 & 6.38 & 3.94 & 6.73 & 1.73 & 11.94 & & + & ns & - & ns \\
\hline & 4 & 7 & 4.27 & 2.67 & 2.84 & 2.42 & 8.69 & & ++ & $\mathrm{ns}$ & ns & - \\
\hline
\end{tabular}

Concentrations of mandelic acid are expressed as the arithmetical mean of values collected over the course of three weeks. $\mathrm{N}-$ number of individuals, $\mathrm{M}-$ arithmetical mean, SD - standard deviation, Med - median, Min - minimum value, Max - maximum value, Significance of test results: $+p<0.05 ;++p<0.01 ;+++p<0.001 ; n s p>0.05$. Profession: 1 - laminating, 2 - milling and finalizing, 3 - laying-up and spraying-up, 4 - background support.

Table 5 shows the MA concentrations of individual workers normalized to BMI. The final normalized MA value for each employee was given as the ratio:

$$
\mathbf{x}_{\mathrm{i}}=\left(\mathbf{M A}_{\text {postshift }}-\mathbf{M A _ { \text { morning } }}\right) / \mathbf{B M I}
$$

$\mathrm{x}_{\mathrm{i}}$ - normalized MA value

$\mathrm{MA}_{\text {morning }}-\mathrm{MA}$ concentration at the beginning of the workshift $(\mathrm{mg} / \mathrm{L})$ $\mathrm{MA}_{\text {postshift }}-\mathrm{MA}$ concentration at the end of the workshift $(\mathrm{mg} / \mathrm{L})$ BMI - body mass index $\left(\mathrm{kg} / \mathrm{m}^{2}\right)$

These normalized values take into account significant interpersonal differences in initial concentrations of MA in urine as well as general condition of the whole metabolism. It is apparent that although the observed differences in normalized MA concentrations were statistically significant (Kruskal-Wallis test $\mathrm{p}<0.03$ ), the greatest differences in normalized MA values between professions were toward the end of week.
The next hypothesis was the question about possible cumulation of MA in worker's organism. Occupational exposure in hand lamination work in the reinforced plastics industry may result in a daily intake of styrene via inhalation (1). Data from 28 plants producing reinforced plastics products in the US showed that the average exposure to styrene in workers involved in open mould processes was two to three times higher than that experienced by workers involved in press-mould processes: $24-82 \mathrm{ppm}$ versus 11-26 ppm (20). In an extensive survey of the reinforced plastics industry in Finland, styrene levels in $77 \%$ of the respiratory zones of lamination workers was found to exceed the safety standard of $20 \mathrm{ppm}$, and the mean 8-hour time-weighted average (TWA) was 43 ppm (21). In the Slovak Republic, the tolerable value of TWA is 20 ppm (19), while in the Czech Republic it is 23 ppm and in the US $50 \mathrm{ppm}$. For example, the concentration of MA in urine that corresponds to inhalation of $50 \mathrm{ppm}$ styrene $(213 \mathrm{mg} /$ $\mathrm{m}^{3}$ ) for $8 \mathrm{~h}$ would be approximately $800-900 \mathrm{mg} / \mathrm{g}$ creatinine 
Table 6. Concentrations of mandelic acid concentrations in $\mathrm{mg} / \mathrm{L}$ within a week at the beginning of the work shift

\begin{tabular}{|c|c|c|c|c|c|c|c|c|}
\hline \multirow{2}{*}{ Profession } & \multirow{2}{*}{ Day } & \multicolumn{7}{|c|}{ Statistical analysis } \\
\hline & & $\mathrm{n}$ & M & SD & Med & Min & Max & $p$ \\
\hline \multirow{4}{*}{1} & Monday & 11 & 253.10 & 166.41 & 180.40 & 82.60 & 591.60 & \multirow{4}{*}{$\mathrm{ns}$} \\
\hline & Tuesday & 11 & 296.28 & 110,46 & 277.00 & 140.20 & 484.30 & \\
\hline & Thursday & 11 & 271.10 & 129.88 & 288.10 & 89.60 & 565.50 & \\
\hline & Friday & 11 & 262.28 & 89.71 & 279.30 & 41.60 & 390.90 & \\
\hline \multirow{4}{*}{2} & Monday & 11 & 0.76 & - & 0.76 & 0.76 & 0.76 & \multirow{4}{*}{$+t$} \\
\hline & Tuesday & 11 & 38.75 & 47.50 & 0.76 & 0.76 & 131.30 & \\
\hline & Thursday & 11 & 56.17 & 65.90 & 35.80 & 0.76 & 168.10 & \\
\hline & Friday & 11 & 62.38 & 56.38 & 51.20 & 0.76 & 187.50 & \\
\hline \multirow{4}{*}{3} & Monday & 6 & 39.40 & 45.53 & 20.75 & 3.00 & 107,30 & \multirow{4}{*}{$+t$} \\
\hline & Tuesday & 6 & 84.12 & 64.94 & 81.00 & 3.00 & 186.00 & \\
\hline & Thursday & 6 & 93.50 & 27.73 & 92.20 & 54.20 & 136.00 & \\
\hline & Friday & 6 & 112.23 & 36.63 & 127.65 & 65.50 & 146.00 & \\
\hline \multirow{4}{*}{4} & Monday & 7 & 0.76 & - & 0.76 & 0.76 & 0.76 & \multirow{4}{*}{++} \\
\hline & Tuesday & 7 & 2.04 & 1.20 & 3.00 & 0.76 & 3.00 & \\
\hline & Thursday & 7 & 11.05 & 24.30 & 3.00 & 0.76 & 66.10 & \\
\hline & Friday & 7 & 15.17 & 22.43 & 3.00 & 0.76 & 51.20 & \\
\hline
\end{tabular}

Concentrations of mandelic acid are expressed as the arithmetical mean of values collected over the course of three weeks. $\mathrm{N}-$ numbers of individuals, $\mathrm{M}-$ arithmetical mean, SD - standard deviation, Med - median, Min - minimum value, Max - maximum value. Significance of Friedman test results: ++ $p<0.01$; ns $p>0.05$. Profession: 1 - laminating, 2 - milling and finalizing, 3 - laying-up and spraying-up, 4 - background support.

Table 7. Concentrations of mandelic acid concentrations ( $\mathrm{mg} / \mathrm{L})$ within a week at the end of the work shift

\begin{tabular}{|c|c|c|c|c|c|c|c|c|}
\hline \multirow{2}{*}{ Profession } & \multirow{2}{*}{ Day } & \multicolumn{7}{|c|}{ Statistical analysis } \\
\hline & & $\mathrm{n}$ & M & SD & Med & Min & Max & $p$ \\
\hline \multirow{4}{*}{1} & Monday & 11 & 824.00 & 547.09 & 763.90 & 201.20 & 2016.70 & \multirow{4}{*}{ ns } \\
\hline & Tuesday & 11 & 786.53 & 400.33 & 804.70 & 220.60 & 1471.20 & \\
\hline & Thursday & 11 & 761.28 & 208.96 & 711.10 & 529.50 & 1239.70 & \\
\hline & Friday & 11 & 1011.75 & 617.70 & 865.90 & 321.30 & 2641.90 & \\
\hline \multirow{4}{*}{2} & Monday & 11 & 122.78 & 36.94 & 129.6 & 68.20 & 190.50 & \multirow{4}{*}{+} \\
\hline & Tuesday & 11 & 145.80 & 60.05 & 143.70 & 65.10 & 129.20 & \\
\hline & Thursday & 11 & 170.15 & 74.39 & 141.9 & 100.60 & 310.90 & \\
\hline & Friday & 11 & 210.65 & 120.60 & 178.40 & 135.40 & 473.20 & \\
\hline \multirow{4}{*}{3} & Monday & 6 & 188.95 & 82.83 & 161.55 & 114.80 & 310.10 & \multirow{4}{*}{ ns } \\
\hline & Tuesday & 6 & 288.87 & 82.29 & 305.40 & 137.40 & 376.50 & \\
\hline & Thursday & 6 & 249.69 & 97.21 & 232.85 & 145.80 & 422.40 & \\
\hline & Friday & 6 & 278.97 & 79.62 & 280.70 & 189.00 & 408.60 & \\
\hline \multirow{4}{*}{4} & Monday & 7 & 104.84 & 48.45 & 90.10 & 57.30 & 188.10 & \multirow{4}{*}{ ns } \\
\hline & Tuesday & 7 & 111.87 & 42.20 & 119.30 & 31.00 & 165.60 & \\
\hline & Thursday & 7 & 127.59 & 71.46 & 115.70 & 37.90 & 246.90 & \\
\hline & Friday & 7 & 109.70 & 63.95 & 76.10 & 60.40 & 220.10 & \\
\hline
\end{tabular}

Concentrations of mandelic acid are expressed as the arithmetical mean of values collected over the course of three weeks. $\mathrm{N}-$ number of individuals, $\mathrm{M}-$ arithmetical mean SD - standard deviation, Med - median, Min - minimum value, Max - maximum value, Significance of Friedman test results: + $p<0.05 ; n s p>0.05$. Profession: $1-$ laminating, 2 - milling and finalizing, 3 - laying-up and spraying-up, 4 - background support. Numerical values of means and medians above biological limit (640 mg/L) in bold.

at the end of a shift and 300-400 $\mathrm{mg} / \mathrm{g}$ creatinine the following morning (22).

However, in a study of workers exposed to $37 \mathrm{ppm}$ (8-hour TWA) styrene, no evidence of accumulation was found over the course of a working week $(4,23)$. As can be seen in Tables 6 and 7 , there is insufficient data to address this question. The only group in which MA concentration remained invariant was the one of laminating workers, whose styrene exposure was so high that no 
day-to-day variation was marked. Both workers engaged in layingup and spraying-up operations and those involved in background support showed significantly increased MA concentrations at the beginning of the work shift $(\mathrm{p}=0.01)$, but these values are well within safe limits $(640 \mathrm{mg} / \mathrm{L})$.

It is notable that the second category of workers (involved in milling and finalizing), exhibited increasing MA concentrations not only at the beginning of the shift $(p=0.003)$, but also at the end $(p=0.04)$. However, all of these values were well within safe limits $(640 \mathrm{mg} / \mathrm{L})($ Table 6,7$)$. One possible explanation for this lies in the nature of the manufacturing process which involves a finalization stage and therefore presents a chance for increased styrene exposure towards the end of the work shift.

\section{CONCLUSION}

Our results show that even in high-tech work environments equipped with protective equipment such as respirators, styrene still represents a significant threat to workers. We measured significantly elevated concentrations of MA greatly in excess of the biological exposure limit of $640 \mathrm{mg} / \mathrm{L}$. All of our results suggest that the intensity of styrene exposure is directly proportional to MA concentrations in urine. Employees working directly with materials containing styrene in a styrene rich environment had higher concentrations of MA in urine compared to their colleagues.

We did not reject the hypothesis about a possible cumulative effect of styrene exposure which merits further studies of its metabolites in human body. On the other hand, MA concentrations in all subjects fell within the biological limits. These minimal concentrations did not appear to be severe, but we believe that there may be risks of long-term exposure.

\section{Conflict of interest}

None declared

\section{REFERENCES}

1. Somorovská M, Jahnová E, Tulinská J, Zámecníková M, Sarmanová J, Terenová A, et al. Biomonitoring of occupational exposure to styrene in a plastics lamination plant. Mutat Res. 1999 Jul 16;428(1-2):255-69.

2. Drbohlav P, Bencko V, Masata J, Jirsová S. Effect of toxic substances in the environment on reproduction. Ceska Gynekol. 2004 Jan;69(1):20-6. (In Czech.)

3. Henderson LM, Speit G. Review of the genotoxicity of styrene in humans. Mutat Res. 2005 May;589(3):158-91.

4. Rueff J, Teixeira JP, Santos LS, Gaspar JF. Genetic effects and biotoxicity monitoring of occupational styrene exposure. Clin Chim Acta. 2009 Jan;399(1-2):8-23.

5. Csanády GA, Kessler W, Hoffmann HD, Filser JG. A toxicokinetic model for styrene and its metabolite styrene-7,8-oxide in mouse, rat and human with special emphasis on the lung. Toxicol Lett. 2003 Feb 18;138(1-2):75102.
6. Boffetta P, Adami HO, Cole P, Trichopoulos D, Mandel JS. Epidemiologic studies of styrene and cancer: a review of the literature. J Occup Environ Med. 2009 Nov;51(11):1275-87.

7. Wong O, Trent LS, Whorton MD. An updated cohort mortality study of workers exposed to styrene in the reinforced plastics and composites industry. Occup Environ Med. 1994 Jun;51(6):386-96.

8. Kolstad HA, Lynge E, Olsen J, Breum N. Incidence of lymphohematopoietic malignancies among styrene-exposed workers of the reinforced plastics industry. Scand J Work Environ Health. 1994 Aug;20(4):272-8.

9. Nedelcheva V. Interaction of styrene and ethylmethylketone in the induction of cytochrome P450 enzymes in rat lung, kidney and liver after separate and combined inhalation exposures. Cent Eur J Public Health. 1996 May;4(2):115-8.

10. Fustinoni S, Manini P, Campo L, De Palma G, Andreoli R, Mutti A, et al. Assessing variability and comparing short-term biomarkers of styrene exposure using a repeated measurements approach. Toxicol Lett. 2010 Jan 15;192(1):40-4.

11. Manini P, Buzio L, Andreoli R, Goldoni M, Bergamaschi E, Jakubowski $\mathrm{M}$, et al. Assessment of biotransformation of the arene moiety of styrene in volunteers and occupationally exposed workers. Toxicol Appl Pharmacol. 2003 Jun 15;189(3):160-9.

12. Haufroid V, Buchet JP, Gardinal S, Ghittori S, Imbriani M, Hirvonen, et al. Importance of genetic polymorphisms of drug-metabolizing enzymes for the interpretation of biomarkers of exposure to styrene. Biomarkers. 2001;6(3):236-49.

13. De Palma G, Manini P, Mozzoni P, Andreoli R, Bergamaschi E, Cavazzini $\mathrm{S}$, et al. Polymorphism of xenobiotic-metabolizing enzymes and excretion of styrene-specific mercapturic acids. Chem Res Toxicol. 2001 Oct;14(10):1393-400.

14. Ghittori S, Imbriani M, Pezzagno G, Capodaglio E. The urinary concentration of solvents as a biological indicator of exposure: proposal for the biological equivalent exposure limit for nine solvents. Am Ind Hyg Assoc J. 1987 Sep;48(9):786-90.

15. Reska M, Ochsmann E, Kraus T, Schettgen T. Accurate quantification of mercapturic acids of styrene (PHEMAs) in human urine with direct sample injection using automated column-switching high-performance liquid chromatography coupled with tandem mass spectrometry. Anal Bioanal Chem. 2010 Aug;397(8):3563-74.

16. Eitaki Y, Kawai T, Kishi R, Sakurai H, Ikeda M. Stability in urine of authentic phenylglyoxylic and mandelic acids as urinary markers of occupational exposure to styrene. J Occup Health. 2008;50(3):221-8.

17. Ogata M, Taguchi T. Simultaneous determination of urinary creatinine and metabolites of toluene, xylene, styrene, ethylbenzene and phenol by automated high performance liquid chromatography. Int Arch Occup Environ Health. 1988;61(1-2):131-40.

18. IARC Working Group on the Evaluation of Carcinogenic Risks to Humans. Some industrial chemicals. IARC Monogr Eval Carcinog Risks Hum. 1994;60:1-560.

19. Government Regulation No. $355 / 2006$ on health protection of workers from risks related to exposure to chemical agents at work, as amended. Zbierka zakonov SR. 2006;125:2550-78. (In Slovak.)

20. Lemasters GK, Carson A, Samuels SJ. Occupational styrene exposure for twelve product categories in the reinforced-plastics industry. Am Ind Hyg Assoc J. 1985 Aug;46(8):434-41.

21. Sorsa M, Anttila A, Järventaus H, Kubiak R, Norppa H, Nylander L, et al. Styrene revisited-exposure assessment and risk estimation in reinforced plastics industry. Prog Clin Biol Res. 1991;372:187-95.

22. IARC Working Group on the Evaluation of Carcinogenic Risks to Humans. Some traditional herbal medicines, some mycotoxins, naphthalene and styrene. IARC Monogr Eval Carcinog Risks Hum. 2002;82:1-556.

23. World Health Organization. Styrene. In: Air quality guidelines. Copenhagen: WHO Regional Officce for Europe; 2000. p. 106-8. 